also made numerous contributions to the stratigraphy and palæontology of the Carboniferous rocks, particularly of Belgium. His published works deal with, among other subjects, fossil plants, coal resources and tectonics. Dr. F. E. Wright of the Geophysical Laboratory, Carnegie Institution, Washington, has investigated the optical properties of minerals, including variations due to changes of temperature. $\mathrm{He}$ has also written on the petrological microscope and the surface features of the moon.

Coming to the new Foreign Correspondents, Prof. N. L. Bowen, of Chicago, formerly a member of the staff of the Geophysical Laboratory, Washington, is an authority on the crystallization of magmas and the evolution of igneous rocks. His work is widely known, and has had considerable influence in Great Britain. Prof. R. M. Field, of Princeton University, has carried out researches upon marine sediments, particularly of the West Indies, and has described the geology of the Bahamas. He has also compared the Ordovician succession in Great Britain and America. Baron F. von Huene, professor in the University of Tübingen, is well known for his studies of fossil reptiles, particularly those of the Trias and Lias. $\mathrm{He}$ has described forms from Central Europe, South Africa, North and South America, India, and Great Britain. His larger works include monographs on the dinosaurs and ichthyosaurs. Prof. H. Stille, of Berlin, is the author of numerous papers on the geology of Westphalia, Hanover and other parts of Germany, many of them dealing with the Cretaceous system. He has also made a special study of tectonic geology, both in its broader aspects and in relation to particular areas, such as the western Mediterranean.

\section{The Royal Veterinary College and Hospital}

Their Majesties the KING and QUEen opened on November 9 the new buildings of the Royal Veterinary College, Great College Street, Camden Town, London, N.W.1. A brochure issued to commemorate this event gives a brief history of the College, and an account of its reconstruction, with a description of the new buildings and of the work that will be carried on in them. The brochure is sumptuously produced, and is illustrated with a portrait of Charles Vial de St. Bel, the first principal (1791-93), as frontispiece, three views of the old College buildings, and a plan of the reconstructed College with views of some of its chief features. The old College has been demolished, and the new College block is rectangular in shape, with projecting wings facing Great College Street, the various departments being grouped around two internal courts separated by a central assembly hall. The Beaumont Hospital for Sick Animals and the Canine Hospital are situated to the west, and the Pathologieal Museum and Pathological Research Institute to the east, of the main block. Behind the Canine block are a reception stable, harness room, garage and workshop. Along the north-east boundary is the Ride in which horses are tested for soundness, horse-boxes, stores and quarters for attendants. The post-mortem building with cold store, preparation room and laboratories adjoins the Ride. Future extensions planned when funds permit are the Large Animals' Hospital and a field station.

\section{Society of Glass Technology : Twenty-first Anniversary}

THE Society of Glass Technology began a two days anniversary meeting on November 9 to celebrate its Coming of Age. The proceedings opened with a luncheon that was attended by the vice-chancellor of the University of Sheffield and Mrs. Pickard. Cambridge, Mrs. F. Wood, Lord Cozens-Hardy, Mr. Geoffrey Pilkington, Mr. W. L. Chance and many other prominent glass manufacturers. In addition, the Society had as its guests four foreign delegates from the Continent, namely, Prof. A. J. de Artigas (Spain), Prof. G. Keppeler (Germany), Dr. B. Long (France), and Dr. H. Maurach (Germany). Of the eighteen original members who still retain their connexion with the Society, thirteen attended. The toast of the Society was proposed by Dr. A. W. Pickard-Cambridge, who spoke of the good effect of such scientific societies internationally and said he looked forward to a time when the University could do more towards developing the artistic side. He concluded by thanking the Society for its generosity in promising to contribute $£ 2,500$ towards the Elmfield Fund. The toast was supported by Prof. Keppeler (representing the Deutsche Glastechnische Gesellschaft) and $\mathbf{M r}$. S. B. Bagley, president of the Glass Manufacturers Federation.

IN the evening the presidential address to the Society was given by Prof. W. E. S. Turner, who reviewed the progress in the glass industry during the past twenty-one years. He showed how the development of machine methods, for which we have largely to thank America, has resulted every. where in the displacement of skilled labour, so that the eraftsman has been fighting a losing battle. On the following day a number of technical papers were read. The morning session was opened by the reading of congratulatory messages from members and friends from Germany, Belgium, Denmark, Italy, United States, Canada, and Africa, after which the status of honorary fellow of the Society was conferred upon Dr. H. Maurach of the Deutsche Glastechnische Gesellschaft (Germany) and Dr. Ross C. Purdy of the American Ceramic Society. Dr. Maurach, who with Prof. G. Keppeler represented the German Society, then presented a congratulatory address, after he and a number of ordinary fellows had signed the roll. The address was contained in a magnificently engraved cylinder of glass mounted in silver at the ends, the work of Prof. von Eiff of Stuttgart, and was enclosed in a casket.

\section{New Buildings for Glass Research at Sheffield}

ON Tuesday, November 9, a ceremony having an element of novelty took place in connexion with the new buildings at present being erected for the Department of Glass Technology of the University of Sheffield. This was the laying of a foundation 